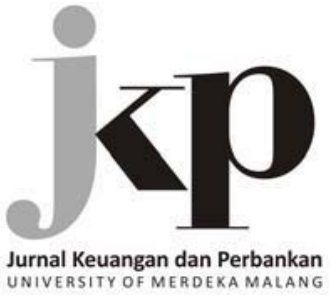

Article history:

Received: 2017-09-22

Revised: 2017-12-06

Accepted: 2018-01-13

Ima Andriyani, Rosalina Pebrica, Mayasari, dan Dwi Septa Aryani Department of Management Faculty of Economy Universitas Tridinanti

Jl. Kapten Marzuki No.2446, Palembang, 30129, Indonesia

$\triangle$ Corresponding Author:

Ima Andriyani:

Tel +62 711355961

E-mail: ima_andriyani@yahoo.co.id
Ima Andriyani (Indonesia), Rosalina Pebrica (Indonesia),
Mayasari (Indonesia), Dwi Septa Aryani (Indonesia)

\section{Soundness Rating of Commercial Banks Before and After Implementation of RGEC Method in Indonesia}

\begin{abstract}
This research aims to analyze the differences in soundness of commercial banks before and after the implementation of Risk Profile, Good Corporate Governance, Earning, Capital (RGEC) method in Indonesia. The unit of analysis was a commercial bank with purposive sampling method of 10 banks. The study period was 2008-2016. Data analysis technique was using comparative test with different test of t-test for related sample. Hypothesis testing with paired sample t-test and data processing with SPSS 24. The research findings showed that the research model based on $\mathrm{F}$ test is fit so that the model formed can be used to test the difference of soundness level of commercial banks. Referring to each RGEC variable, it was found that the risk profile proxy with Non Performing Loan (NPL) and earning with proxy Net Interest Margin (NIM) not significant before and after RGEC implementation while Good Corporate Governance (GCG) and Capital Adequacy Ratio (CAR) have significant difference before and after the implementation of RGEC. This study for GCG testing still used self assessment which can be seen from the score of each bank directly.
\end{abstract}

Keywords: Capital; Earning; Good Corporate Governance; Risk Profile

JEL Classification: G21, G34

Citation: Andriyani I., Mayasari R. P., \& Aryani D. S. (2018). Soundness rating of commercial banks before and after implementation of RGEC Method in Indonesia. Jurnal Keuangan dan Perbankan, 22(1): 162-169. https:/ / doi.org/ 10.26905/jkdp.v22i1.1549

\begin{abstract}
Abstrak
Penelitian ini bertujuan untuk menganalisis perbedaan tingkat kesehatan bank umum sebelum dan sesudah implementasi metode Risk Profile, Good Corporate Governance, Earning, Capital (RGEC) di Indonesia. Unit analisis adalah bank umum dengan metode purposive sampling sebanyak 10 bank. Periode penelitian adalah 2008-2016. Teknik analisis data menggunakan uji komparatif dengan uji beda t-test untuk related sample. Pengujian hipotesis dengan paired sample t-test dan pengolahan data dengan SPSS 24. Temuan penelitian menunjukkan bahwa model penelitian berdasarkan uji F adalah fit sehingga model yang dibentuk dapat digunakan untuk menguji perbedaan tingkat kesehatan bank umum. Merujuk pada masing-masing variabel RGEC ditemukan bahwa profil risiko yang diproksi dengan Non Performing Loan (NPL) dan laba yang diproksi Net Interest Margin (NIM) terbukti tidak memiliki perbedaan signifikan sebelum dan sesudah implementasi RGEC sedangkan good corporate governance dan permodalan diproksi oleh Capital Adequacy Ratio (CAR) terbukti memiliki perbedaan signifikan antarasebelum dan sesudah implementasi RGEC. Penelitian ini untuk pengujian GCG masih menggunakan penilaian self assessment yang langsung dapat dilihat dari skor masing-masing bank.
\end{abstract}

Kata kunci: Modal, Laba, Good Corporate Governance, Profil Risiko. 
The global financial crisis experience led to increase the risk implementation effectiveness and Good Corporate Governance (GCG) for the banking in Indonesia. The objective is that banks are able to identify problems earlier so that they can take appropriate and faster remedial action for the banking activities sustainability. Risk management and GCG implementation is expected to be more resilient the banks in the face of crisis. GCG Implementation will reduce some of the interest turmoil and marginalize information asymmetry so as to reduce the cost of nonperforming loans elimination (Bastomi, Salim, \& Aisjah., 2017).

The fundamental objective of the banking business is to obtain optimal benefits by providing financial services to the community (Yuliani, 2016). If the bank is able to maintain its performance well, especially its high profitability, the business prospects can always grow and be able to fulfill the prudential banking requirements. The bank's business activities include three aspects including funding, lending and providing services to the community. The synergy of these business activities will maximize profit during the bank operation, which the bank is required to have better earnings performance. Profit performance becomes one of the reflections of bank's soundness criteria that are earnings ratio. The bank soundness measurement is done thoroughly to find out the success of banking so that necessary method in assessing bank soundness.

The current rating of bank soundness in Indonesia has been using RGEC method through PBI No.13/1/PBI/ 2011 and SEBI No.13/24/DPNP as of January 2012 supersedes the old method of bank soundness assessment by CAMELS method. The stages in RGEC are risk-oriented, proportionality, materiality, significance, comprehensive and structured by requiring commercial banks to conduct selfassessment and consolidation. Several previous studies on the RGEC method are more descriptive research designs such as Ramadhany, Suhadak, \&
Zahroh (2015), while the Putri \& Damayanthi (2013) study by looking at the differences between large and small banks using RGEC found that there was no difference in soundness level between large and small banks. Research with the object of commercial banks and using RGEC method has been done by some researchers such as Anggraini \& Dzulkirom (2013), Kusumawati (2014), dan Ramadhany, Suhadak \& Zahroh (2015).

In accordance with the PBI No.13/1/PBI/ 2011 concerning the commercial banks rating, banks are required to conduct a bank rating based on the RiskBased Bank Rating. Bank's soundness level assessment is performed on an individual or consolidated basis. The stages of the bank's assessment of RGEC may be called the bank's soundness assessment model that is loaded with risk management. According to central bank (Bank of Indonesia), bank management needs to consider to the following general principles as a basis for assessing bank soundness: risk-oriented, proportionality, materiality and significance, as well as comprehensive and structured. The research framework is shown in Figure 1.

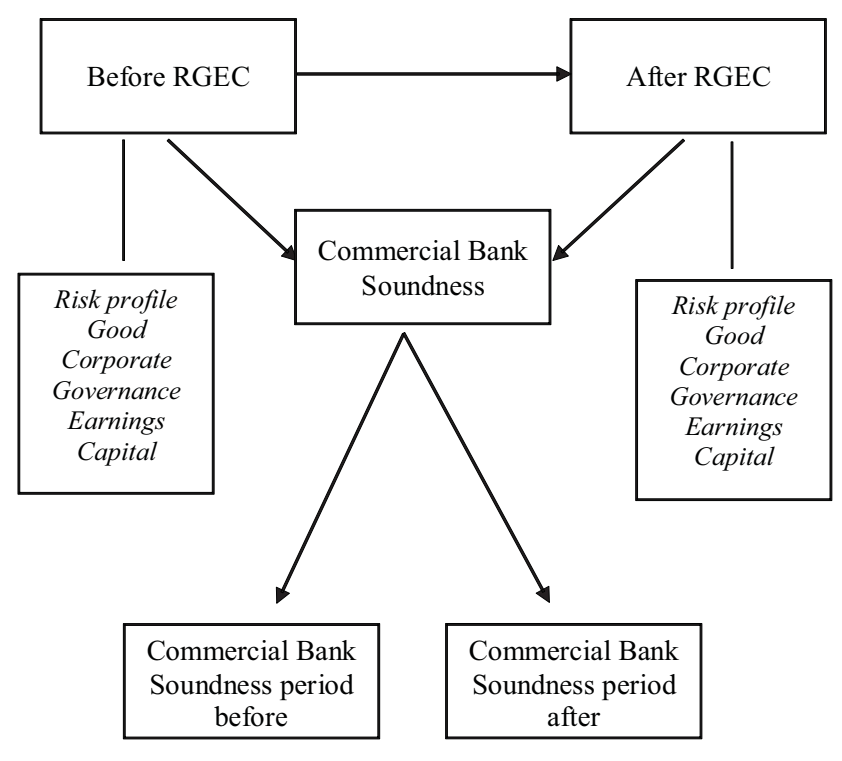

Figure 1. The research framework 
This study aims to examine the other side of previous research that is to see the difference before and after the implementation of RGEC at commercial banks in Indonesia in particular the period after three years of implementation. The next section of this paper is to explain the method of research, research results and discussion of research results. The final part of the paper is conclusions, suggestions and limitations.

\section{HYPOTHESES DEVELOPMENT}

Risk profile is defined as the risk of giving credit to the debtor. The risk profile variable proxyed by Non Performing Loan (NPL) is the percentage of non performing loans (with criteria of substandard, doubtful and loss) to the total loan disbursed by the bank. More higher for these ratios, the worse bank credit quality, will higher the number of non-performing loans, the possibility of a bank in increasingly troubled conditions. The results of Iqbal (2017) showed that the impact was large for conventional banks if there is an increase in non-performing loans. The impact of the NPL will have a significant effect on the achievement of bank profit so that in the end with the application of RGEC method the bank will book an optimum profit.

$\mathrm{H}_{1}$ : there is a significant difference of risk profile between before and after implementation of RGEC method.

Good Corporate Governance (GCG) is a system used to direct and control the business activities of a company (Ali, 2006). GCG can also be interpreted as the relationship between board of commissioners, board of directors, stakeholders, and company shareholders. Based on PBI No.13/1/ 2011 which requires the banks in Indonesia to incorporate GCG factor into one of the bank soundness rating, the company necessary to have a big responsibility in maintaining the stability of the banking system so as to obtain the title implementation of soundness corporate governance.
$\mathrm{H}_{2}$ : there is significant difference between Good Corporate Governance between before and after the implementation of the RGEC method.

Profitability is the bank ability to make a profit. The element of bank income depends on the services offered by the bank. Banks provide loans, invest portfolios, and make remittances and other services. The bank receives income consisting of interest on the loan or compensation for the services provided by the bank and the gain on portfolio investment. Profitability assessment factor using Net Interest Margin (NIM) ratio. This ratio describes the level of the amount of net interest income earned by using assets owned by the bank, so the greater the value NIM then the greater the gains from interest income and would affect the soundness of the bank's financial performance.

$\mathrm{H}_{3}$ : there is a significant difference between the earning before and after the implementation of the RGEC method

Capital factor assessment includes evaluation of capital adequacy and adequacy of capital management. Capital valuation using Capital Adequacy Ratio (CAR). If the lower owned CAR means the smaller the bank's capital to assume risky assets, the greater the likelihood that the bank will experience a problem condition because the bank's capital does not suffer enough to decrease the value of risky assets, and vice versa if high CAR means capital owned to bear the risk asset is also higher so that the lower experiencing troubled condition because of capital owned by bank will more bigger.

$\mathrm{H}_{4}$ : there is significant capital difference between before and after implementation of RGEC method

\section{METHODS}

The source of research data is secondary data by accessing Indonesian banking directory from 


\section{Soundness Rating of Commercial Banks Before and After Implementation of RGEC Method in Indonesia}

Ima Andriyani, Rosalina Pebrica Mayasari, Dwi Septa Aryani

www.bi.go.id and www.ojk.go.id and Infobank Magazine from 2008-2017. Data collection is a documentation study. The population of this study are all commercial banks in Indonesia amounted to 119 based on Indonesian Banking Statistics 2014. Sampling was done by purposive sampling method. Sample criterion is banks has the largest asset and had good performance and have data according to research variable. Based on the criteria selected by 10 commercial banks, namely Bank Mandiri Tbk, Bank BRI Tbk, Bank BNI Tbk, Bank BTN Tbk, Bank BCA Tbk, Bank CIMB Niaga Tbk, Bank Pan Indonesia Tbk and Bank Permata Tbk, Bank Danamon Indonesia Tbk, and Bank Mega Tbk. The research design is an explanation with the type of comparative research that describes the differences because there is a particular situation or event that is the implementation of RGEC method. Data analysis techniques are descriptive and inferential statistically. Hypothesis testing using paired t-test for paired samples.

Variables used in the study refer to the provisions of the bank's soundness assessment by us- ing RGEC. The definitions and measurements of RGEC are presented in Table 1.

\section{RESULTS}

The results are discussed descriptively and inferentially. Descriptive statistical results provide an overview of the soundness of commercial banks with RGEC method before and after its application. The following is the result of the description of the data in Table 2.

Table 2 shows that the average NPL of commercial banks in this study is $3.77 \%$, which means that the riskprofile profile with NPLs before the RGEC method is applied is better than after the RGEC. After the implementation of RGEC there was an average decrease of $2.67 \%$. This shows that the implementation of RGEC able to reduce the NPL in commercial banks that become the research sample. Referring to the description of the data after the NPL is lower than the NPL before.

The composite value of GCG between before and after on average for commercial banks became

Table 1. Operational Definition and Variable Measurement

\begin{tabular}{|c|c|c|c|}
\hline Variable & Definition & Proxy & Measurement \\
\hline Risk Profile & $\begin{array}{l}\text { Risk factors assessment using credit risk } \\
\text { assessment (non performing loans) }\end{array}$ & NPL & $\frac{\text { Total NPL }}{\text { Total Credits }} \times 100 \%$ \\
\hline $\begin{array}{l}\text { Good Corporate } \\
\text { Governance }\end{array}$ & $\begin{array}{l}\text { A system that manages and controls the } \\
\text { company to create added value for the } \\
\text { parties concerned }\end{array}$ & GCG & $\begin{array}{l}\text { Composite value: } \\
\text { Composite Value }<1.5 \text { (very good) } \\
1.5 \leq \text { Composite Value }<2.5 \text { (good) } \\
2.5 \leq \text { Composite Value }<3.5 \text { (good enough) } \\
3.5 \leq \text { Composite Value }<4.5 \text { (poor) } \\
4.5 \leq \text { Composite Value }<5 \text { (not good) }\end{array}$ \\
\hline Earning & The ability of banks to make a profit. & NIM & $\frac{\text { Net interest income }}{\text { Average Earning Assets }} \times 100 \%$ \\
\hline Capital & $\begin{array}{l}\text { Measuring the adequacy of bank capital } \\
\text { to anticipate potential losses according to } \\
\text { the risk profile, which is accompanied by } \\
\text { very strong capital management in } \\
\text { accordance with the characteristics, } \\
\text { business scale and complexity of the } \\
\text { bank's business }\end{array}$ & CAR & $\frac{\text { Capital }}{\text { ATMR }} \times 100 \%$ \\
\hline
\end{tabular}


better ie GCG before 0.00 and after increasing is 1.78. The composite value before 0.00 is due to the new RGEC effective 2012 so that GCG data before the implementation of RGEC is not yet available. This shows that the importance for banks in business activities to notice to good corporate governance based on the basic principles of GCG set by the regulator in Indonesia.

The average earning size projected by NIM between pre and post is also different. The average NIM before RGEC is lower than the average NIM after RGEC. This means that after the enactment of RGEC, the bank seeks to increase the NIM derived from interest income.

The CAR variable as a proxy of capital shows good results because on average there is an increase after RGEC is applied. The average CAR before is $15.84 \%$ and after $17.93 \%$ means the bank is trying to increase the capital adequacy ratio so that the public will be guaranteed the funds saved. The maximum CAR value between before and after also happen difference. CAR increase between before and after, meaning commercial bank in Indonesia from side of capital adequacy is good.

Table 2 also shows the standard deviation or standard deviation of the research variables. It appears that it is not too different between before and after RGEC for all the variables studied. Based on the explanation above, the descriptive of the variables studied only NPLs which have a difference where after the implementation of RGEC instead of problem loans increased while the other variables show better bank health performance. Prior to hypothesis testing the condition of use of $t$-test paired is to be ensured normality of data. This study has 40 data so that the normality testing tool uses the Shapiro-Wilk test. The result of normality test data was shown in Table 3.

Table 3 shows that NPL after, before and after GCG, NIM before and after are not normally distributed. It means that the data distribution because the number of observations is relatively small so that although not normally distributed can still be continued for testing the hypothesis before the

Table 2. Descriptive Statistic ( $N=40)$

\begin{tabular}{llcccc}
\hline \multicolumn{1}{c}{ Variable } & condition & Minimum & Maximum & Average & Standar Deviation \\
\hline NPL (\%) & Before & 0.49 & 18.63 & 3.77 & 4.48 \\
& After & 0.38 & 8.83 & 2.67 & 1.71 \\
GCG & Before & 0.00 & 0.00 & 0.00 & 0.00 \\
NIM (\%) & After & 1.00 & 3.00 & 1.78 & 0.58 \\
& Before & 1.60 & 11.30 & 6.11 & 2.12 \\
CAR (\%) & After & 0.87 & 9.60 & 6.02 & 1.61 \\
& Before & 10.85 & 21.79 & 15.84 & 2.44 \\
\hline
\end{tabular}

Table 3. Shapiro-Wilk Normality Test

\begin{tabular}{llccl}
\hline \multicolumn{1}{c}{ Variable } & Condition & Statistic & Sig & Description \\
\hline NPL $(\%)$ & Before & 0.613 & 0.000 & Not normally distribution \\
& After & 0.767 & 0.000 & Not normally distribution \\
GCG & Before & - & - & - \\
NIM $(\%)$ & After & 0.000 & 0.000 & Not normally distribution \\
& Before & 0.885 & 0.001 & Not normally distribution \\
CAR $(\%)$ & After & 0.945 & 0.050 & Normal distribution \\
& Before & 0.968 & 0.305 & Normal distribution \\
& After & 0.930 & 0.017 & Not normally distribution \\
\hline
\end{tabular}




\section{Soundness Rating of Commercial Banks Before and After Implementation of RGEC Method in Indonesia}

Ima Andriyani, Rosalina Pebrica Mayasari, Dwi Septa Aryani

hypothesis testing will be discussed about the relationship between bank soundness levels before and after RGEC can be seen in Table 4.

Table 4 shows the relationship between the NPL variables before and after the RGEC method implementation. It appears that there is no correlation or correlation between NPLs before and after RGEC at á $=5 \%$. It means that non-performing loans in commercial banks in the sample research have not proven to be correlated. Furthermore, GCG variables before and after RGEC proved no correlation with the test results on the significance of more than $5 \%$ so that it can be interpreted that commercial banks after applied RGEC then the bank soundness level that there is no correlation. NIM before and after the implementation of RGEC proved to have a strong and significant correlation shown by the correlation number of 0.744 and the significance level is less than $5 \%$. The CAR variable as a proxy of capital indicates no correlation. This means that CAR before and after the implementation of RGEC there is no correlation.

After the normality and correlation testing then followed by testing the hypothesis by using a paired t-test or known as t-test paired. The test aims to compare a similar variable but observations made at different times or periods. The paired t-test results are shown in Table 5.

\section{DISCUSSION}

The findings of the study appear in Table 5 that there is no significant difference in soundness of commercial banks as measured by risk profile before and after the implementation of RGEC. These findings provide empirical evidence yet that after the implementation of RGEC accordance with PBI No.13 / 1 / NT / 2011 where the banks in compulsory soundness assessment using a risk-based approach. One of the measurements is the risk profile. There is no difference in NPL before and after the implementation of RGEC indicates that commercial banks in fund allocation activities are still based on prudential principles so that NPL do not experience significant differences.

Risk profile banking includes credit risk, liquidity risk, market risk, operational, law, strategy, compliance and reputation. Proxy of risk profile in this research is the risk measured by using the financial statements is the risk of how much banks have problem loans or known as the performance of Non Performing Loan (NPL). NPL measurement by looking at the percentage of nonperforming loans to total loans disbursed banks. The smaller the value of NPL then the performance of the bank will be better. The provision of OJK is $<5 \%$ it means performance is smaller will be better. The findings of this study differ from the results of research (Putri

Table 4. Relationship Before and After RGEC

\begin{tabular}{lcc}
\hline & Corrrelation & Sig. \\
\hline Pair 1 NPL Before and After & -0.017 & 0.917 \\
Pair 2 GCG Before and After & 0.000 & 0.000 \\
Pair 3 NIM Before and After & 0.744 & 0.000 \\
Pair 4 CAR Before and After & -0.207 & 0.201 \\
\hline
\end{tabular}

Table 5. Hypothesis Test Results with t-test paired

\begin{tabular}{lrrl}
\hline & $\mathbf{t}$ & Sig. (2-tailed) & Keterangan \\
\hline Pair 1 NPL Before and After & 1.436 & 0.159 & $\mathrm{H}_{1}$ Rejected \\
Pair 2 GCG Before and After & -19.463 & 0.000 & $\mathrm{H}_{2}$ Accepted \\
Pair 3 NIM Before and After & 0.386 & 0.701 & $\mathrm{H}_{3}$ Rejected \\
Pair 4 CAR Before and After & -3.257 & 0.002 & $\mathrm{H}_{4}$ Accepted \\
\hline
\end{tabular}


\& Damayanthi, 2013) in which the study distinguishes between large banks and small banks by using the Mann-Whitney test method. The risk profile variable was found to have significant differences.

GCG before and after the implementation of RGEC is empirically proven. The results showed that there are significant differences in GCG variables obtained from self assessment with the final value is a composite of weights 1 to 5 . The findings on GCG are consistent with Putri \& Damayanthi (2013) for the category of large banks and small banks. The results of previous research indicate that there are differences in GCG between large and small banks.

The findings of this study for differentiated earnings test projected with NIM showed no difference. Empirical evidence of this study indicates that NIM which is the difference between savings and loan interest rates is more influenced by Governance regulation in this case OJK and BI. This provision refers to the BI rate which would be an external factor for banks to adjust the provisions. The high NIM shows the higher the bank's financial performance This research uses NIM while previous research is more using ROA as in Anggraini \& Dzulkirom (2013), Hendrayana \& Yasa (2015), Kusumawati (2014), Marselina (2017), Ramadhany, Suhadak, \& Zahroh (2015), dan Wulandari \& Mertha (2017).

Findings about capital differences before and after the implementation of RGEC found results that there are significant differences. These findings were able to provide empirical evidence that after the implementation of the general bank RGEC in this study there is a improvement. Commercial banks seek to maintain capital adequacy because soundness insurance for the sustainability of bank business activities can be seen from the adequacy of capital. Capital is proxyed by CAR is the ability of banks to guarantee their own capital with risk-weighted assets. The minimum standard CAR is $8 \%$ and the higher value will be better.

CAR before RGEC implementation is $15.84 \%$. This figure indicates that commercial banks have a very soundness category of capital ratios before the implementation of RGEC. The fact also shows after the implementation of RGEC an increase in the average CAR ratio of commercial banks almost $19 \%$.

The bank's capital becomes the size of the bank group because the banking regulation in Indonesia has classified the banks according to the size of core capital calculated based on Commercial Banks and Business Activities (BUKU). Each BUKU is based on core capital group where for group with core capital IDR 30 trillion and above is BUKU 4; BUKU 3 has a core capital of IDR 5 trillion to under IDR 30 trillion; BUKU 2 has a core capital of IDR 1 trillion to under IDR 5 trillion and BUKU 1 has a core capital below IDR 1 trillion.

The findings of this study are consistent with the results of research Kusumawati (2014) and Yuliani (2007) that the CAR contributes to the increase in bank profits and RGEC method is able to increase the CAR so that in the end the bank's performance becomes better..The results of this study In contrast to Putri \& Damayanthi, (2013) that there is no difference CAR between large banks and small banks. The results of Marselina (2017) study indicate that there is no CAR effect on earnings changes with the RGEC approach. Similarly, the results of research (Witjaksono \& Nathalia, 2014) that the CAR has no effect on stock returns for banks in groups of BUKU 3 and BUKU 4.

\section{CONCLUSION AND SUGGESTIONS}

\section{Conclusion}

Risk profile projected with NPL after the implementation of RGEC proved to have no significant difference. GCG variables proved significant after RGEC implementation, earnings did not have 


\section{Soundness Rating of Commercial Banks Before and After Implementation of RGEC Method in Indonesia}

Ima Andriyani, Rosalina Pebrica Mayasari, Dwi Septa Aryani

significant differences while capital proved significantly different after the application of RGEC.

\section{Suggestions}

Commercial banks that carry out activities to raise funds, allocate funds and provide services to the public need to notice the bank performance, especially the ratios used with the RGEC method. Two different ratios with the CAMELS method of risk profile and good corporate governance make the bank required self assessment so that the valuation application based on composite value makes the bank must have good performance with existing process.

This study has limitations on GCG data which for 2008-2011 is not yet available so future research if want to re-test the application of RGEC for the period starts is after 2012. This research is based on quantitative ratios so that qualitative in-depth information has not been accommodated. This research has not differentiated banks according to core capital in BUKU 3 and BUKU 4 so that future research can be analyzed by differentiating banks according to the BUKU group.

\section{REFERENCES}

Anggraini, M., Dzulkirom, M., \& Saifi, M. (2015). Analisis tingkat kesehatan bank dengan menggunakan pendekatan RGEC. Jurnal Administrasi Bisnis, 27(1), 211-216.

Bastomi, M., Salim, U., \& Aisjah, S. (2017). The role of corporate governance and risk management on banking financial performance in Indonesia. Jurnal Keuangan dan Perbankan, 21(40), 589-599.

Hendrayana, P. W., \& Yasa, G. W. (2015). Pengaruh komponen RGEC pada perubahan harga saham perbankan di Bursa Efek Indonesia. E-Jurnal Manajemen Unud, 10(2), 554-569.

Iqbal, M. (2017). Perbandingan Pengelolaan risiko kredit perbankan syariah dan perbankan konvensional. Jurnal Keuangan dan Perbankan, 21(3), 481-497.
Kusumawati, M. (2014). Analisis komparatif kinerja keuangan perbankan berdasarkan metode CAMELS dan RGEC pada PT. Bank Mandiri (Persero) Tbk. Jurnal Akuntansi Unesa, 2(2), 1-22. https://doi.org/ 10.1017/CBO9781107415324.004

Putri, I. D. A. D. E., \& Damayanthi, I. G. A. E. (2013). Analisis perbedaan tingkat kesehatan bank berdasarkan RGEC pada perusahaan perbankan besar dan kecil. E-Jurnal Akuntansi Universitas Udayana, 5(2), 483496.

Ramadhany, A. P., Suhadak, \& Zahroh, Z. (2015). Analisis perbandingan tingkat kesehatan bank berdasarkan risk profile, Good Corporate Governance, earnings dan capital (RGEC) pada bank konvensional BUMN dan swasta (Studi pada Bank Umum Milik Negara dan Bank Swasta Nasional Devisa yang terdaftar di bursa. Jurnal Administrasi Bisnis, 23(1), 1-9.
Thalib, D. (2016). Intermediasi, struktur modal, efisiensi, permodalan dan risiko terhadap profitabilitas bank. Jurnal Keuangan dan Perbankan, 20(1), 116-126.

Witjaksono, A., \& Nathalia, M. (2014). Pengaruh tingkat kesehatan bank berdasarkan metode RGEC terhadap return saham pada perusahaan perbankan go public di Indonesia Stock Exchange (IDX) Tahun 20112012. Jurnal GICI, 4(3), 20-33.

Wulandari, D. A. E., \& Mertha, M. (2017). Penerapan regulasi bank terkait penilaian RGEC dan dampaknya pada nilai perusahaan perbankan. EJurnal Manajemen Unud, 18(1), 790-817.

Yuliani. (2007). Hubungan efisiensi operasional dengan kinerja profitabilitas pada sektor perbankan yang go public di Bursa Efek Jakarta. Jurnal Manajemen $\mathcal{E}$ Bisnis Sriwijaya, 5(10), 13-41. 